J. Perinat. Med. 17 (1989) 127

\section{Placental transport of calcium and phoshorus in pigs}

\author{
Ute Lachenmaier-Currle and Johein Harmeyer
}

Institute of Physiology, School of Veterinary Medicine, Hannover, West Germany

\section{Introduction}

Accretion of calcium (Ca) and phosphorus $(\mathrm{P})$ in fetal bone requires active transport from mother to fetus through the placenta. Although active transport of $\mathrm{Ca}$ and $\mathrm{P}$ has been described in sheep and in various other species $[1,25,22]$ the factors mediating this process are not yet clear. One possible candidate for the regulation is vitamin D [23]. Support for this view comes from the presence of specific placental $1,25-(\mathrm{OH})_{2} \mathrm{D}_{3}$ receptors in rats, from the presence of a vitamin $\mathrm{D}$ dependent calcium-binding protein (CaBP) $[3,18]$ and from placental 25-hydroxycholecalciferol-1-hydroxylase activities in humans [27] rats [24] and in guinea pigs [7].

In sheep, for example, fetal plasma levels of 1,25$(\mathrm{OH})_{2} \mathrm{D}_{3}$ appear to be a primary factor for the regulation of transplacental $\mathrm{Ca}$ transport [5]. Other evidence, however, from Brommage and Deluca [2] indicated that transfer of $\mathrm{Ca}$ and $\mathrm{P}$ through the placenta of rats is independent of both maternal and fetal $1,25-(\mathrm{OH})_{2} \mathrm{D}_{3}$ concentrations. From measuring feto-meternal concentration ratios of $\mathrm{Ca}$ and $\mathrm{P}$ in vitamin $\mathrm{D}$ deficient and in vitamin $\mathrm{D}$ repleted mother/fetus systems these authors found that transplacental gradients were unaffected by the presence of $1,25-(\mathrm{OH})_{2} \mathrm{D}_{3}$ in either mother or fetus.

We have investigated the transport of $\mathrm{Ca}$ and $\mathrm{P}$ in pigs, using the "Hannover Pig Strain". These pigs suffer from inherited pseudo-vitamin D-deficiency rickets, type I [13]. They lack the renal cholecalciferol-1-hydroxylase activity [28] and have unphysiological low concentrations of $1,25-$ $(\mathrm{OH})_{2} \mathrm{D}_{3}$ in plasma. The animals depend on permanent pharmacological treatment with vitamin D [13] to prevent development of hypocalcemia, hypophosphatemia and florid rickets. The disease

\section{Curriculum vitae}

Ute LACHENMAIERCURRLE, M. D. was born in 1956 in Stuttgart. She studied food technology during 1976-1982 at the University of Hohenheim near Stuttgart. She worked during 1982-1987 as research fellow at the Institute of Physiology, Veterinary School of Hannover where she completed her

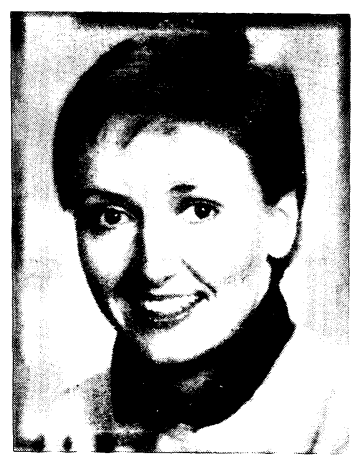
Ph.D. Thesis. She specialized in problems of vitamin $D$ metabolism and vitamin $D$ function as related to metabolic bone diseases.

is inherited by an autosomal recessive gene and clinical symptoms develop only in homozygote progeny [19]. The symptoms which develop at an age of four to six weeks [10] are almost identical to those found in humans with pseudo-vitamin Ddeficiency rickets, type I [20]. Ca and P concentrations in plasma of homozygote rachitic piglets, however, are normal at birth. It was investigated which role vitamin D plays in regulating placental transport of $\mathrm{Ca}$ and $\mathrm{P}$ during the perinatal period in these pigs.

\section{Material and methods}

\subsection{Animals and feeding}

Thirty nine homozygote and heterozygote offspring of five litters from five sows were used for the study. To produce homozygote and heterozygote offspring a homozygote and a heterozygote parent animal were mated. Seventeen homozygote 
piglets were produced by mating one homozygote and two heterozygote sows with one homozygote boar. Twenty two control piglets (heterozygotes and normals) were generated by mating one homozygote and three heterozygote sows with one homozygote and one normal control boar (table I).

The sows and boars were fed twice daily a grain/ concentrate pig diet at maintainance level which contained $0.8 \% \mathrm{Ca}$ and $0.6 \% \mathrm{P} / \mathrm{kg} \mathrm{DM}$.

Table I. Experimental animals and status (ho $=$ homozygote, $\mathrm{h}=$ heterozygote)

\begin{tabular}{lll}
\hline $\begin{array}{l}\text { Sow No. } \\
\text { and status }\end{array}$ & $\begin{array}{l}\text { Boar No. } \\
\text { and status }\end{array}$ & $\begin{array}{l}\text { Number of } \\
\text { offspring } \\
\text { and genotype } \\
\text { ho/he }\end{array}$ \\
\hline 1 Homozygote & 1 homozygote & $\begin{array}{r}10: 10 / 0 \\
8: 0 / 8\end{array}$ \\
2 Homozygote & 2 normal & $8: 0 / 8^{*}$ \\
3 Heterozygote & 2 normal & $6: 3 / 3$ \\
5 Heterozygote & 1 homozygote & $7: 4 / 3$ \\
\hline
\end{tabular}

* approximately $50 \%$ heterozygote and $50 \%$ normal genotype

\subsection{Blood sampling and analytical procedures}

Adult homozygote animals were treated by i.m. injections of $10 \mathrm{mg}$ of vitamin $\mathrm{D}_{3}$ at intervals of four weeks. With the sows, treatment was discontinued from two months before conception to one day to one week after delivery. Two to $5 \mathrm{ml}$ of arterial and venous blood were collected by puncture from the umbilical vessels during cesarian section at the $114^{\text {th }}$ to $115^{\text {th }}$ day of pregnancy. The sows were prepared for cesarian section by i.m. injection of 3 to $5 \mathrm{ml}$ Azaperon (Stresnil (B) and i.v. injection of 3 to $6 \mathrm{ml}$ Metomidat- $\mathrm{HCl}(\mathrm{Hyp}-$ nodil (B) and epidural anesthesia with $0.7-1.2 \mathrm{ml}$ of a local anesthetic agent (Hostacain (B)). After finishing blood collection the umbilical cord was disconnected to separate the piglets from maternal blood supply. Maternal blood was obtained before parturition and during the operation by indwelling catheters from the internal jugular vein. The catheters were placed two to three weeks before parturition under anesthesia. The blood was heparinized and centrifuged at $3500 \mathrm{~g}$ for $10 \mathrm{~min}$ and the plasma was stored in $1.0 \mathrm{ml}$ aliquots for further analysis at $-25^{\circ} \mathrm{C}$. Plasma $\mathrm{Ca}$ was colorimetrically determined in $50 \mu \mathrm{l}$ aliquots as cresolphtalein- complex using the Boehringer Test Kit (No. 204382). The vatiation coefficient of the replicates at different times was $\pm 2 \%$. Inorganic $P$ was measured in plasma as molybdenumblue-complex [21]. The variation coefficient was $+3 \%$.

The concentration of $1,25-\left(\mathrm{OH}_{2} \mathrm{D}_{3}\right.$ was measured after separation of the methanol/methylenchloride extract by HPLC, following a procedure of LAMBERT et al. [15] and KAUNE and HARMEYER [11].

Briefly, 2 to $4 \mathrm{ml}$ of plasma were extracted with a mixture of methanol/methylenchloride $(2+1$, $\mathrm{v} / \mathrm{v})$. The extract was fractionated on columns with Lipidex 5000 (Fa. Packard Instr. \& Co., Hamburg, FRG) using a three step gradient of n-hexane in chloroform. The $3^{\text {rd }}(45+55, \mathrm{v} / \mathrm{v})$ hexane in chloroform mixture eluated the double hydroxylated metabolites of vitamin $D$. This fraction was brought to dryness and separated by normal phase HPLC. The HPLC elution program constituted of a $30 \mathrm{~min}$ gradient of isopropanol in $\mathrm{n}$-hexane. The eluated fractions which contained $1,25-(\mathrm{OH})_{2} \mathrm{D}_{3}$ were combined and brought to dryness and quantified by a radioimmunoassay using an antibody from sheep, kindly provided by A. D. CARE, Dept. Animal Physiology and Nutrition, University of Leeds, GB. The reference substances were kindly provided by Hoffmann-La Roche, Basel, Basel, Switzerland.

For recovery measurements known amounts of 1,25-dihydroxy $\left(26,27\right.$-methyl- $\left.{ }^{3} \mathrm{H}\right)$-cholecalciferol (spec. activity: $6.51 \mathrm{TBq} / \mathrm{mmol}$; Fa. Amersham Buchler, Braunschweig, FRG) were added before extraction of plasma. The intra- and interassay variances were $+14 \%(n=16)$ and $9.2 \%(n=8)$, respectively.

\subsection{Statistics}

Differences in the plasma $\mathrm{Ca}$ and $\mathrm{P}$ concentrations between groups were tested with Student's t-test with different numbers of $\mathrm{n}$ in the two groups. The aterio-venous differences in fetal plasma were tested of significance with a paired t-test.

\section{Results}

\subsection{Fetal and maternal concentrations of $\mathrm{Ca}$ and $P$ in plasma}

a) Calcium: Mean concentrations of $\mathrm{Ca}$ in heterozygote sows at parturition were $2.34 \mathrm{mmol} / \mathrm{l}$ and significantly higher than those in homozygote sows $(1.58 \mathrm{mmol} / \mathrm{l})$ (table II). Ca concentrations 
Table II. Concentrations of calcium (mmol/l) in maternal and fetal plasma of pigs at term (mean \pm SD).

\begin{tabular}{|c|c|c|c|c|c|c|}
\hline \multirow{2}{*}{$\begin{array}{l}\text { Group of } \\
\text { animals }\end{array}$} & \multirow{2}{*}{$\begin{array}{l}\text { (I) } \\
\text { Maternal plasma } \\
\text { jugular vein } \\
\text { (n) }\end{array}$} & \multirow{2}{*}{$\begin{array}{l}\text { (II) } \\
\text { Arterial plasma } \\
\text { fetus (V. umb) } \\
\text { (n) }\end{array}$} & \multirow{2}{*}{$\begin{array}{l}\text { (III) } \\
\text { Concentration } \\
\text { difference }\end{array}$} & \multicolumn{3}{|c|}{ significance } \\
\hline & & & & $\begin{array}{l}\text { between } \\
\text { rows }\end{array}$ & $\begin{array}{l}\text { for } \\
\text { column }\end{array}$ & $\mathrm{p}<$ \\
\hline $\begin{array}{l}\text { 1) Homozygote sows and } \\
\text { their fetuses }\end{array}$ & $\begin{array}{l}1.58 \pm 0.18 \\
(6)\end{array}$ & $\begin{array}{l}2.96 \pm 0.08 \\
(15)\end{array}$ & $1.35 \pm 0.14$ & $\begin{array}{l}1: 2 \\
1: 2 \\
1: 2\end{array}$ & $\begin{array}{l}\text { (I) } \\
\text { (II) } \\
\text { (III) }\end{array}$ & $\begin{array}{l}0.001 \\
\text { n.s. } \\
0.001\end{array}$ \\
\hline $\begin{array}{l}\text { 2) Heterozygote sows and } \\
\text { their fetuses }\end{array}$ & $\begin{array}{l}2.34 \pm 0.07 \\
(6)\end{array}$ & $\begin{array}{l}3.23 \pm 0.10 \\
(17)\end{array}$ & $0.909 \pm 0.10$ & & & \\
\hline $\begin{array}{l}\text { 3) Heterozygote sows and } \\
\text { their heterozygote fetuses }\end{array}$ & $\begin{array}{l}2.34 \pm 0.07 \\
(6)\end{array}$ & $\begin{array}{l}3.22 \pm 0.05 \\
(11)\end{array}$ & $0.887 \pm 0.08$ & $3: 4$ & (II) & n.s. \\
\hline $\begin{array}{l}\text { 4) Heterozygote sows and } \\
\text { their homozygote fetuses }\end{array}$ & $\begin{array}{l}2.29 \pm 0.10 \\
(2)\end{array}$ & $\begin{array}{l}3.25 \pm 0.04 \\
(6)\end{array}$ & $0.965 \pm 0.08$ & & & \\
\hline $\begin{array}{l}\text { 5) Homozygote sows and } \\
\text { their heterozygote fetuses }\end{array}$ & 1.76 & $\begin{array}{l}2.99 \pm 0.07 \\
(8)\end{array}$ & $1.23 \pm 0.07$ & $5: 6$ & (II) & n.s. \\
\hline $\begin{array}{l}\text { 6) Homozygote sows and } \\
\text { their homozygote fetuses }\end{array}$ & 1.45 & $\begin{array}{l}2.91 \pm 0.06 \\
(7)\end{array}$ & $1.46 \pm 0.06$ & & & \\
\hline
\end{tabular}

in arterial plasma of fetuses from homozygote and heterozygote sows were $2.96 \mathrm{mmol} / 1$ and 3.23 $\mathrm{mmol} / \mathrm{l}$, respectively, and were statistically not different (table II; $1: 2$ (II) n. s.). Although fetal Ca in offspring from hypocalcemic homozygote sows was slightly lower than that in offspring from normocalcemic heterozygote mothers the fetal/ maternal Ca gradient was significantly greater in the homozygote mother/piglet system than that in the heterozygote mother/piglet system (figure $1 \mathrm{~A}$, table II). Plasma $\mathrm{Ca}$ in homozygote and in heterozygote offspring from the same sows was the same showing that the genotype of the fetus had no significant influence on the feto/maternal concentration gradient (table II; $5: 6$ (II) n. s.).

b) Phosphate: The mean concentration of $P$ in plasma of heterozygote sows at parturition (2.33 $\mathrm{mmol} / \mathrm{l})$ was also significantly higher than that in homozygotes, $1.26 \mathrm{mmol} / \mathrm{l}$ (table III). Fetal con-

Table III. Concentrations of phosphate (mmol/l) in maternal and fetal plasma of pigs at term (mean \pm SD).

\begin{tabular}{|c|c|c|c|c|c|c|}
\hline \multirow{2}{*}{$\begin{array}{l}\text { Group of } \\
\text { animals }\end{array}$} & \multirow{2}{*}{$\begin{array}{l}\text { (I) } \\
\text { Maternal plasma } \\
\text { jugular vein } \\
\text { (n) }\end{array}$} & \multirow{2}{*}{$\begin{array}{l}\text { (II) } \\
\text { Arterial plasma } \\
\text { fetus (V. umb) } \\
\text { (n) }\end{array}$} & \multirow{2}{*}{$\begin{array}{l}\text { (III) } \\
\text { Concentration } \\
\text { difference }\end{array}$} & \multicolumn{3}{|c|}{ Significance } \\
\hline & & & & $\begin{array}{l}\text { between } \\
\text { rows }\end{array}$ & $\begin{array}{l}\text { for } \\
\text { column }\end{array}$ & $\mathrm{p}<$ \\
\hline $\begin{array}{l}\text { 1) Homozygote sows and } \\
\text { their fetuses }\end{array}$ & $\begin{array}{l}1.26 \pm 0.186 \\
(6)\end{array}$ & $\begin{array}{l}2.82 \pm 0.270 \\
(13)\end{array}$ & $1.51 \pm 0.265$ & $\begin{array}{l}1: 2 \\
1: 2 \\
1: 2\end{array}$ & $\begin{array}{l}\text { (I) } \\
\text { (II) } \\
\text { (III) }\end{array}$ & $\begin{array}{l}0.001 \\
\text { n.s. } \\
0.001\end{array}$ \\
\hline $\begin{array}{l}\text { 2) Heterozygote sows and } \\
\text { their fetuses }\end{array}$ & $\begin{array}{l}2.33 \pm 0.09 \\
(6)\end{array}$ & $\begin{array}{l}2.82 \pm 0.184 \\
(16)\end{array}$ & $0.65 \pm 0.201$ & & & \\
\hline $\begin{array}{l}\text { 3) Heterozygote sows and } \\
\text { their heterozygote fetuses }\end{array}$ & $\begin{array}{l}2.23 \pm 0.09 \\
(6)\end{array}$ & $\begin{array}{l}2.77 \pm 0.170 \\
(10)\end{array}$ & $0.57 \pm 0.276$ & $3: 4$ & (II) & n.s. \\
\hline $\begin{array}{l}\text { 4) Heterozygote sows and } \\
\text { their homozygote fetuses }\end{array}$ & $\begin{array}{l}2.28 \pm 0.09 \\
(2)\end{array}$ & $\begin{array}{l}2.89 \pm 0.194 \\
(6)\end{array}$ & $0.79 \pm 0.204$ & & & \\
\hline $\begin{array}{l}\text { 5) Homozygote sows and } \\
\text { their heterozygote fetuses }\end{array}$ & 1.42 & $\begin{array}{l}2.88 \pm 0.275 \\
(8)\end{array}$ & $1.46 \pm 0.276$ & $5: 6$ & (II) & n.s. \\
\hline $\begin{array}{l}\text { 6) Homozygote sows and } \\
\text { their homozygote fetuses }\end{array}$ & 1.16 & $\begin{array}{l}2.73 \pm 0.262 \\
(6)\end{array}$ & $1.57 \pm 0.262$ & & & \\
\hline
\end{tabular}




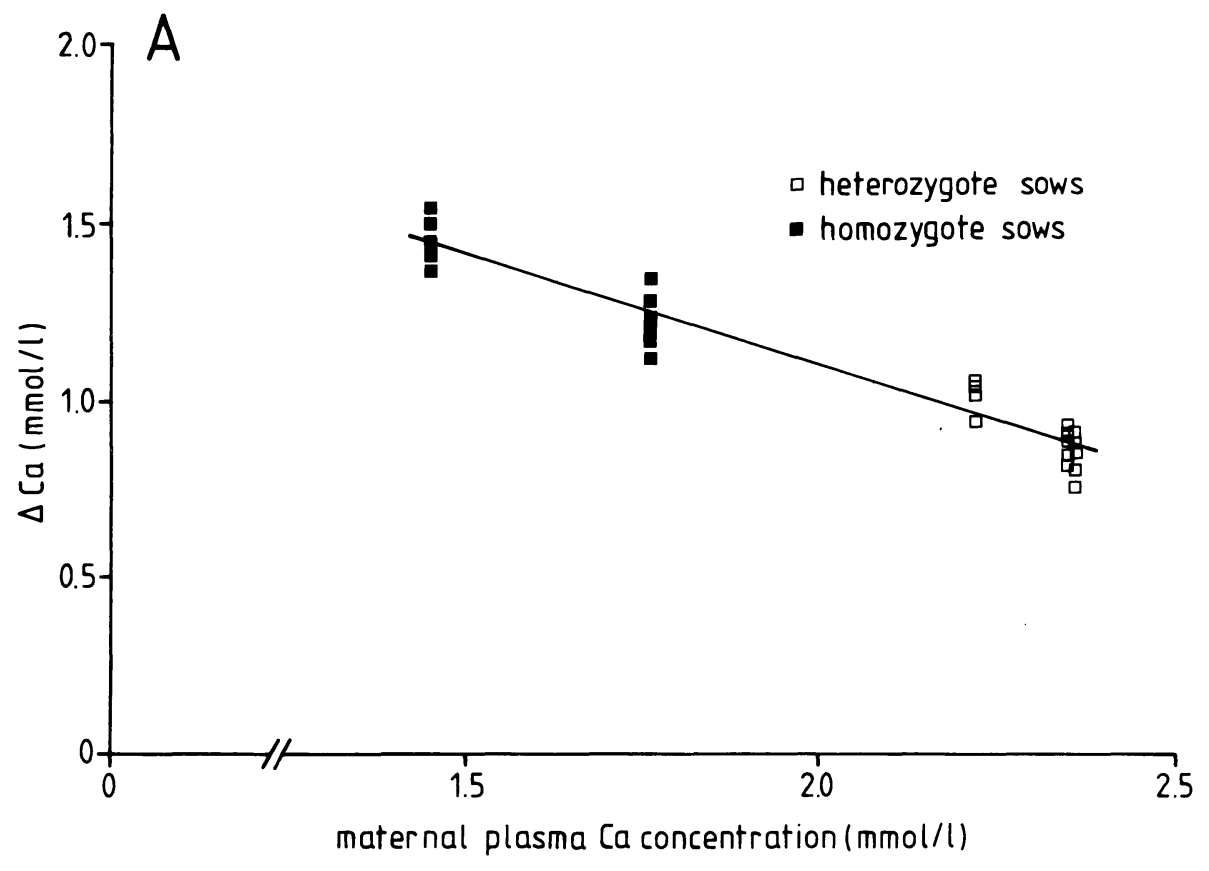

Figure $1 \mathrm{~A}, \mathrm{~B}$. The fetal-maternal concentration difference of $\mathrm{Ca}(\mathrm{A})$ and $\mathrm{Pi}((\mathrm{B})$ ordinate) increases with decrease of $\mathrm{Ca}$ in maternal plasma (abszissa).

Fetal blood was collected from the umbilical vein. Maternal blood was from the external jugular vein.

centrations in arterial plasma of offspring from heterozygote and homozygote mothers, however, were the same $(2.82 \mathrm{mmol} / \mathrm{l}$; table III), also leading to a significantly greater fetal/maternal concentration difference between the homozygote hypophosphatemic mothers and their offspirng (1.26 vs. $2.28 \mathrm{mmol} / \mathrm{l})$ than between the normophosphatemic heterozygote sows and their offspring ( 2.33 vs. $2.82 \mathrm{mmol} / \mathrm{l}$; figure $1 \mathrm{~B}$, table III). Again, no significant effect was exerted by the genotype of the fetus on the feto/maternal gradient (table III).

\subsection{Arterio-venous differences of calcium and phosphate in fetuses}

Concentrations of $\mathrm{Ca}$ and $\mathrm{P}$ in arterial umbilical plasma were consistently higher $(p<0.01)$ than in venous plasma (table IV). No significant influence on the AV-concentration difference appeared to be exerted by the genotype of the fetus (table IV; rows $3: 4$, n.s.). The genotype of the mother seemed to have a slight effect on fetal AV-differences of $\mathrm{Ca}$ which was higher in fetuses from heterozygote sows ( 3.23 vs. $2.96 \mathrm{mmol} / \mathrm{l}$; table IV, $2: 1)$.

3.3 Concentration of $1,25-(\mathrm{OH})_{2} \mathrm{D}_{3}$ in maternal and fetal plasma

a) Mother/fetus relationships: The concentration of $1,25-(\mathrm{OH})_{2} \mathrm{D}_{3}$ of untreated hypocalcemic sows at term was only $30 \%(\mathrm{p}<0.1)$ that of normocalcemic heterozygote sows $(25.5$ vs. $84.1 \mathrm{pg} / \mathrm{ml}$; table V). The fetal vitamin D-hormone concentration in arterial plasma from hypocalcemic sows was $46 \%$ that in plasma of fetuses from normocalcemic sows ( 25.0 vs. $54.1 \mathrm{pg} / \mathrm{ml}$; table V). This indicated that the genotype of the mother exerted an effect on $1,25-(\mathrm{OH})_{2} \mathrm{D}_{3}$ concentrations in plasma of the fetus. This contrasts to what was seen for $\mathrm{Ca}$ and $\mathrm{P}$. The genotype of the fetus had no significant effect on the fetal venous 1,25 $(\mathrm{OH})_{2} \mathrm{D}_{3}$ concentrations in homozygote sows $(44.1$ vs. $39.8 \mathrm{pg} / \mathrm{ml}$; table $\mathrm{V}$ ) but resulted in a higher $1,25-(\mathrm{OH})_{2} \mathrm{D}_{3}$ concentration of heterozygote offspring in heterozygote sows (56.1 vs. 32.8; table V). 


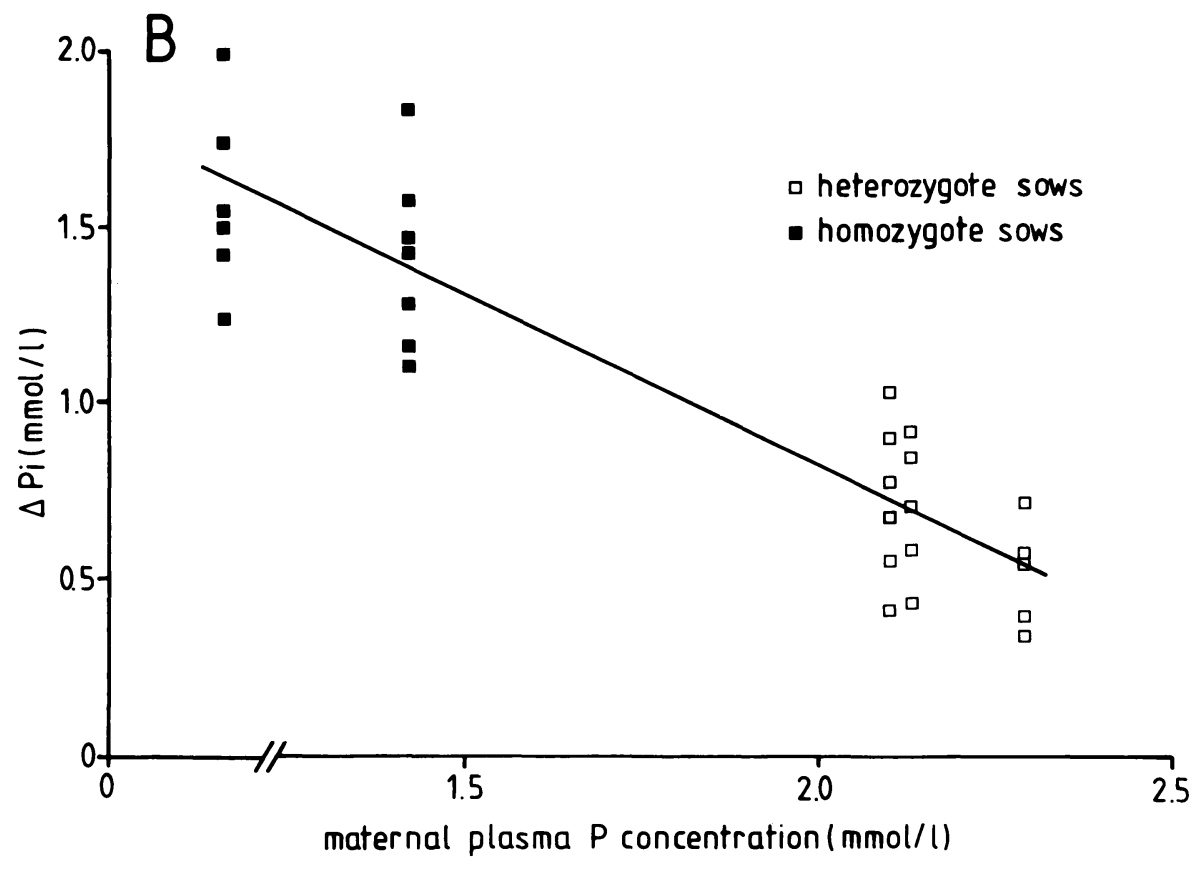

Figure 1 B.

Table IV. Arterial and venous concentrations of calcium and phosphate $(\mathrm{mmol} / \mathrm{l})$ in umbilical plasma of pig fetuses at term (mean $\pm \mathrm{SD})$.

\begin{tabular}{lllllll}
\hline Group of fetuses & $\begin{array}{l}\text { (I) } \\
\text { Arterial plasma } \\
\text { (V. umb) }\end{array}$ & (n) & $\begin{array}{l}\text { (II) } \\
\text { Venous plasma } \\
\text { (Aa. umb) }\end{array}$ & (n) & $\mathrm{n}$ & $\mathrm{p}<$ \\
\hline $\begin{array}{l}\text { 1) Fetuses from } \\
\text { homozygote sows }\end{array}$ & $\mathrm{Ca}: 2.96 \pm 0.08$ & $(15)$ & $2.89 \pm 0.09$ & $(17)$ & $(14)$ & 0.01 \\
$\begin{array}{l}\text { 2) Fetuses from } \\
\text { heterozygote sows }\end{array}$ & P: $2.82 \pm 0.270$ & $(13)$ & $2.19 \pm 0.104$ & $(14)$ & $(12)$ & 0.001 \\
$\begin{array}{l}\text { 3) Homozygote } \\
\text { fetuses from }\end{array}$ & Ca: $3.23 \pm 0.10$ & $(17)$ & $3.11 \pm 0.08$ & $(21)$ & $(17)$ & 0.001 \\
homozygote and & P: $2.87 \pm 0.184$ & $(16)$ & $2.35 \pm 0.109$ & $(14)$ & $(14)$ & 0.001 \\
heterozygote sows & Ca: $2.96 \pm 0.162$ & $(13)$ & $3.07 \pm 0.182$ & $(17)$ & $(13)$ & 0.01 \\
$\begin{array}{l}\text { 4) Heterozygote } \\
\text { fetuses from }\end{array}$ & P: $2.81 \pm 0.236$ & $(12)$ & $2.25 \pm 0.143$ & $(13)$ & $(11)$ & 0.001 \\
homozygote and & & & & & & \\
heterozygote sows & Ca: $3.12 \pm 0.130$ & $(19)$ & $3.04 \pm 0.106$ & $(21)$ & $(18)$ & 0.01 \\
\hline
\end{tabular}

(n) = number of plasma samples, $\mathbf{n}=$ number of differences

b) Arterio-venous differences in fetal plasma: The AV-concentration differences of $1,25-(\mathrm{OH})_{2} \mathrm{D}_{3}$ in plasma of fetuses supplied with the blood from homozygote sows was always negative (42.3 vs.
25.0; table V) but was zero in fetuses which were supplied with blood from heterozygote mothers (47.6 vs. 54.1 ; table V). This effect was not influenced by the genotype of the fetus. 
Table V. Concentrations of $1,25-(\mathrm{OH})_{2} \mathrm{D}_{3}(\mathrm{pg} / \mathrm{ml})$ of maternal and fetal plasma at term (mean \pm SD).

Group of

animals
(I) (II)

Maternal plasma Arterial plasma Venous plasma jugular vein fetus (V. umb)
(III)

fetus (Aa. umb)
Significance

between for co- $\mathrm{p}<$

rows lumn
1) Homozygote sows and their fetuses

2) Heterozygote sows and their fetuses

3) Homozygote fetuses and their sows

4) Heterozygote fetuses and their sows

5) Homozygote fetuses and their heterozygote sows

6) Homozygote fetuses and the homozygote sow

7) Heterozygote fetuses and the heterozygote sow

8) Heterozygote fetuses and the homozygote sow
$25.5 \pm 8.27$

(2)

$84.1 \pm 25.60$

(3)

$76.1 \pm 39.28$

(3)

$69.6 \pm 35.31$

(4)

$98.7 \pm 5.51$

(2)

31.0

(1)

$84.1 \pm 25.60$

19.3

(1)
$25.0 \pm 2.60$

(6)

$54.1 \pm 19.24$

(11)

$35.3 \pm 17.36$

(7)

$49.9 \pm 21.35$

(10)

$41.5 \pm 21.70$

(4)

$27.0 \pm 1.35$

(3)

$61.4 \pm 13.80$

$23.0 \pm 1.83$

(3)
$42.3 \pm 6.69 \quad 1: 2 \quad$ (II)

0.002

(7)

$47.6 \pm 17.31 \quad 1: 2$

(11)

$1: 2$

(I)

0.1

$38.7 \pm 11.40$

$3: 4$

(III)

n.s.

(8)

$54.3 \pm 18.85$

(10)

$32.8+11.73$

$5: 7$

(III)

0.025

(4)

$44.1 \pm 8.54 \quad 6: 8$

n.s.
(4)

$56.1 \pm 14.30$

$39.8 \pm 3.17$

(3)

\section{Discussion}

Investigation of feto-maternal $\mathrm{Ca}$ homeostasis in the "Hannover Pig Strain" showed that the placentas of homozygote hypocalcemic sows maintained significantly greater concentration gradients for $\mathrm{Ca}$ and $\mathrm{P}$ than the placentas of heterozygote sows. Thus the ability of the placenta to transport $\mathrm{Ca}$ and $\mathrm{P}$ to the fetus appears to be independent from the vitamin D-status. There was little doubt about the vitamin $\mathrm{D}$ deficient status of the homozygote sows, since hypocalcemia in the untreated sows was sometimes acute at birth and was associated with cardiovascular symptoms and immobility. In these cases the sows were substituted by continuous intravenous infusions of $\mathrm{Ca}$ immediately after delivery.

Our observations differ somewhat from those of Ross et al. [22] who observed a decrease or increase in fetal $\mathrm{Ca}$ after an acutely induced hypocalcemia and hypercalcemia in pregnant normal sows, respectively. CARE [6] reported, however, that there was no permanent decrease in fetal $\mathrm{Ca}$ after acutely induced (30 to $80 \mathrm{~min}$ ) hypocalcemia in sows by intravenous EDTA-Infusions.
The hypocalcemia in our rachitic sows resulted from discontinuation of vitamin D-treatment and from the lack of renal 1,25- $(\mathrm{OH})_{-} \mathrm{D}_{3}$ production [28]. Maternal 1,25- $(\mathrm{OH})_{2} \mathrm{D}_{3}$ concentrations of 25 $\mathrm{pg} / \mathrm{ml}$ in the homozygote sows were similar to those of nonpregnant adult pigs of the rachitic strain and were always seen to be too low to maintain normocalcemia [13].

The vitamin D-hormone concentration in plasma of homozygote fetuses which were derived from both homozygote and heterozygote sows, of 45 and $33 \mathrm{pg} / \mathrm{ml}$, respectively, are considered to be too low to induce placental transfer of $\mathrm{Ca}$ and $\mathrm{P}$ to the fetus. This is supported by the observation that an extremely low plasma $1,25-(\mathrm{OH})_{2} \mathrm{D}_{3}$ concentration in some homozygote fetuses (considerably below $25 \mathrm{pg} / \mathrm{ml}$ ) showed to have no adverse effect on $\mathrm{Ca}$ and $\mathrm{P}$ transport from the mother into these fetuses. In addition, we found that homozygote and heterozygote piglets at term had no detectable intestinal $1,25-(\mathrm{OH})_{2} \mathrm{D}_{3}$ receptors [12]. The receptor started to appear between 1 and 2 weeks of extra-uterine life. 
The mean 1,25- $(\mathrm{OH})_{2} \mathrm{D}_{3}$ concentrations in plasma of heterozygote fetuses $(54 \mathrm{pg} / \mathrm{ml})$, and in homozygote fetuses $(39 \mathrm{pg} / \mathrm{ml})$ were not correlated with plasma $\mathrm{Ca}$ and $\mathrm{P}$ concentrations of the animals. We conclude from this observation that in pigs potential renal $1,25-(\mathrm{OH})_{2} \mathrm{D}_{3}$ production in either mother of fetus is not essential for maintenance of the $\mathrm{Ca}$ homeostasis of the pig fetus. In addition, both homozygote and heterozygote piglets showed normal intestinal absorption of $\mathrm{Ca}$ during the first two weeks of extra-uterine life [14]. Hypocalcemia and rickets developed in homozygote piglets not before an age of three to five weeks. Vitamin Dhormone concentrations in plasma, however, remained low during the first three to five weeks of life. Other support for the view of placental $\mathrm{Ca}$ transport being independent from vitamin $\mathrm{D}$ comes from studies with vitamin $\mathrm{D}$ depleted pregnant rats [2]. In these studies vitamin D deficient rat fetuses had normal blood concentrations of $\mathrm{Ca}$ and $\mathrm{P}$ [9] and placental gradients of these elements were higher between vitamin $\mathrm{D}$ depleted than between vitamin $\mathrm{D}$ repleted mother/fetuses [2].

The independence of rat placental calbindin from vitamin D [16] lends further support to the view of a vitamin $D$ independent regulation of placental $\mathrm{Ca}$ transport in the rat. A similar finding has been made by TWARDOCK and AUSTIN [25] in guinea pigs who reported that a placental $\mathrm{Ca}$ gradient was also maintained after fetal nephrectomy.

\section{Summary}

The role of vitamin $\mathrm{D}$ in regulating placental transport of calcium and phosphate in pigs was studied using the "Hannover Pig Strain" which suffers from pseudo-vitamin D-deficiency rickets, type I. Sows and fetuses of normal phenotype (heterozygotes) and of homozygote phenotype which suffered from clinical symptoms of rickets were used. The homozygote animals are devoid of renal 25-cholecalciferol-1-hydroxylase. In the rachitic sows which normally depend on treatment with pharmacological doses of vitamin $D_{3}$ at intervals of four to six weeks, vitamin D-treatment was discontinued two months before conception. $\mathrm{Ca}, \mathrm{P}$ and $1,25-(\mathrm{OH})_{2} \mathrm{D}_{3}$ concentrations in plasma of sows and fetuses (Aa. umb., $\mathrm{V}$. umb.) were measured in samples obtained at term during cesarian section.

Mean concentrations of $\mathrm{Ca}$ and $\mathrm{P}$ in heterozygote sows at parturition were $2.34 \mathrm{mmol} / \mathrm{l}$ and $2.33 \mathrm{mmol} / \mathrm{l}$, respectively, and were significantly higher than in homozygote sows, $1.58 \mathrm{mmol} / 1$ and $1.26 \mathrm{mmol} / \mathrm{l}$, respectively.
This contrasts somewhat with observations made in sheep fetuses. In this species fetal nephrectomy resulted in a significant fall of the fetal 1,25$(\mathrm{OH})_{2} \mathrm{D}_{3}$ concentration and abolished the placental gradient for $\mathrm{Ca}[23,17]$. Also in mice placental calbindin appears to be more responsive to the maternal vitamin D supply than in rats [4].

The vitamin D-hormone in maternal and fetal plasma of homozygote animals does not originate from renal production (unpublished observation). Extrarenal production of $1,25-(\mathrm{OH})_{2} \mathrm{D}_{3}$, however, has been demonstrated to occur in pregnant rats $[8,26]$ and in human decidua [27]. We do not think that the slightly higher $1,25-(\mathrm{OH})_{2} \mathrm{D}_{3}$ concentrations in the umbilical venous plasma of heterozygote fetuses $(54 \mathrm{pg} / \mathrm{ml})$ compared to homozygote fetuses $(39 \mathrm{pg} / \mathrm{ml})$ indicate a contribution of the fetal heterozygote kidney to $1,25-(\mathrm{OH})_{2} \mathrm{D}_{3}$ production.

Pig placenta is permeable to $1,25-(\mathrm{OH})_{2} \mathrm{D}_{3}[6]$. The placental differences of $1,25-(\mathrm{OH})_{2} \mathrm{D}_{3}$ found in these studies indicate a placental transfer of 1,25$(\mathrm{OH})_{2} \mathrm{D}_{3}$ from homozygote and heterozygote fetuses to the homozygote sows and from heterozygote sows to the homozygote fetus (table V). The physiological significance of this passage is yet unknown since no significant placental concentration differences of vitamin D-hormone were found in the heterozygote mother/fetus system. This contrasts also with findings in sheep where fetal concentrations of $1,25-(\mathrm{OH})_{2} \mathrm{D}_{3}$ were found to be markedly higher $(88 \mathrm{pg} / \mathrm{ml})$ than in the ewe $(58$ $\mathrm{pg} / \mathrm{ml}$ ) [23].

Ca concentrations in plasma of the umbilical vein of fetuses from both homozygote and heterozygote sows were normal, however, $(3.23 \mathrm{mmol} / 1$ and $2.96 \mathrm{mmol} / \mathrm{l}$, respectively) and statistically not different from each other. No significantly different $P$ concentrations in arterial plasma of fetuses from heterozygote or homozygote sows were seen, either. The concentrations of $\mathrm{Ca}$ and $P$ in the arterial umbilical plasma were significantly higher $(p<0.001)$ than in venous plasma of both homozygote and heterozygote fetuses, indicating net placental transfer of these elements in both genotypes.

The concentration of $1,25-(\mathrm{OH})_{2} \mathrm{D}_{3}$ in hypocalcemic sows at term $(25.5 \pm 8.25 \mathrm{pg} / \mathrm{ml})$ was significantly lower than that in the normocalcemic (heterozygote) sows $(84.1 \pm 25.6 \mathrm{pg} / \mathrm{ml})$. The $1,25-(\mathrm{OH})_{2} \mathrm{D}_{3}$ concentration in arterial plasma of fetuses from homozygote sows was only $46 \%$ that of fetuses from normocalcemic sows which showed transfer of calcitriol from mother to fetus. It is concluded from these studies that in pigs, renal 
production and physiological concentrations of 1,25 $(\mathrm{OH})_{2} \mathrm{D}_{3}$ in either mother or fetus is not essential for the maintainance of the $\mathrm{Ca}$ and $\mathrm{P}$ homeostasis in the fetalmaternal system.

Keywords: Calcium, calcitriol, perinatal period, pigs, phosphorus, transplacental transport, vitamin D.

\section{Zusammenfassung}

\section{Plazentarer Transport von Calcium and Phosphat beim} Schwein

Wir untersuchten die Rolle des Vitamin D bei der Regulation des plazentaren Transports von Calcium und Phosphat am "Hannover Pig Strain", das an einer Rachitis infolge eines Pseudo-Vitamin-D-Mangels (Typ 1) leidet. Muttertiere und Feten mit normalem Phänotyp (Heterozygote) sowie mit klinischen Zeichen der Rachitis (Homozygote) wurden in die Studie einbezogen. Die homozygoten Tiere hatten keine renale 25-Cholecalciferol-1-Hydroxlase. Die Sauen mit Rachitis, die normalerweise pharmakologische Dosen von Vitamin $D_{3}$ in Abständen von 4-6 Wochen erhalten, wurden jetzt zwei Monate vor Konzeption nicht mehr mit Vitamin D behandelt. Die Ca-, P- und 1,25- $(\mathrm{OH})_{2} \mathrm{D}_{3}$-Konzentrationen im Plasma von Muttertieren und Feten (Aa. umb., V. umb.) wurden in Proben gemessen, die während der Geburt bei der Sectio caesarea gewonnen wurden.

Die mittleren Konzentrationen von $\mathrm{Ca}$ und $\mathrm{P}$ waren bei den heterozygoten Muttertieren während der Geburt signifikant höher als bei den homozygoten Tieren (2.34 $\mathrm{mmol} / \mathrm{l}$ und $2.33 \mathrm{mmol} / \mathrm{l}$ gegenüber entsprechend 1.58 $\mathrm{mmol} / \mathrm{l}$ und $1.26 \mathrm{mmol} / \mathrm{l})$. Die Ca-Konzentrationen in der Umbilicalvene der Feten waren bei homozygoten und heterozygoten Tieren normal $(3.23 \mathrm{mmol} / 1$ und 2.96 mmol/l) und statistisch nicht signifikant unterschiedlich. Auch die P-Konzentrationen im arteriellen Plasma der Feten waren bei homozygoten und heterozygoten Müttern vergleichbar. Die Ca- und P-Konzentrationen im Nabelarterienplasma waren jedoch sowohl bei homozygoten wie heterozygoten Feten signifikant höher $(\mathrm{p}<0.001)$, was auf einen Netto-Transport dieser Elemente via Plazenta bei beiden Genotypen hinweist.

Die Konzentration von $1,25-(\mathrm{OH})_{2} \mathrm{D}_{3}$ bei hypocalcämischen Muttertieren zum Geburtszeitpunkt war signifikant niedriger als bei normocalcämischen (heterozygoten) Tieren $(25.5 \pm 8.25 \mathrm{pg} / \mathrm{ml}$ versus $84.1 \pm 25.6 \mathrm{pg} /$ $\mathrm{ml})$. Die 1,25-(OH $)_{2} \mathrm{D}_{3}$-Konzentration im arteriellen Plasma von Föten von homozygoten Sauen betrug lediglich $46 \%$ derjenigen, die bei Feten von normocalcämischen Muttertieren gefunden wurde, was auf einen Calcitriol-Transfer von der Mutter zum Fetus weist.

Wir schließen aus unseren Ergebnissen, daß beim Schwein eine renale Produktion und physiologische Konzentrationen von $1,25-(\mathrm{OH})_{2} \mathrm{D}_{3}$ sowohl bei der Mutter wie beim Feten nicht essentiell sind für die Aufrechterhaltung der $\mathrm{Ca}$ - und P-Homöostase des feto-maternalen Systems.

Schlüsselwörter: Calcium, 1,25-(OH) ${ }_{2} \mathrm{D}_{3}$, Phosphat, plazentarer Transport, Rachitits infolge Vitamin-D-Mangel (Typ 1), Vitamin D.

\section{Résumé}

Transport placentaire du calcium et du phosphore chez le cochon

On a étudié le rôle de la vitamine $\mathrm{D}$ dans la régulation du transport placentaire du calcium chez le cochon en utilisant des truies "Hannover Strain" qui présentent un rachitisme de type I par déficience en pseudo-vitamine D. On a utilisé des truies et des fotus de pheünotype normal (héterozygotes) et de pheünotype homozygote qui présentent des symptomes cliniques de rachitisme. Les animaux homozygotes n'ont pas de 25-cholecalciférol-1-hydroxylase rénale. Chez les truefs rachitiques qui dépendent normalement d'un traitement à doses pharmacologiques de vitamine $D_{3}$, toutes les 4 à 6 semaines, on a interrompu le traitement deux mois avant la conception. Sur des prélèvements obtenus à terme au cours de césariennes, on a mesuré dans le plasma des truies et des fœtus (artère et veine ombilicale) le ca, le $\mathrm{P}$ et la $1,25-(\mathrm{OH})_{2} \mathrm{D}_{3}$.

Lors de la parturition les concentrations moyennes de ca et de $P$ chez les truies hétérozygotes sont de 2,34 $\mathrm{mmol} / 1$ et de $2,33 \mathrm{mmol} / 1$, respectivement, et elles sont significativement plus élevées que chez les truies homo- zygotes, $1,58 \mathrm{mmol} / 1$ et $1,26 \mathrm{mmol} / 1$, respectivement. Les concentrations de ca dans le plasma de la veine ombilicale de fœtus des truies homozygotes et hétérozygotes sont normales, toutefois, (respectivement $3,23 \mathrm{mmol} / 1$ et $2,96 \mathrm{mmol} / \mathrm{l}$ ) et ne sont pas significativement différentes l'une de l'autre. Il n'a pas été trouvé de différences significatives dans les concentrations de $\mathrm{P}$ du plasma artériel chez les fœtus de truies hétérozygotes et homozygotes. Les concentrations de ca et de $\mathrm{P}$ du plasma artériel ombilical sont significativement plus élevées $(\mathrm{p}<0,001)$ que dans le plasma veineux des fœtus homozygotes et hétérozygotes, ce qui traduit un transfert placentaire net de ces éléments, quel que soit le génotype. La concentration de $1,25-(\mathrm{OH})_{2} \mathrm{D}_{3}$ chez les truies hypocalcémiques à terme $(25,5 \mp 8,25 \mathrm{pg} / \mathrm{ml})$ est significativement inférieure à celle des truies normocalcémiques (hétérozygotes) $(84,1 \mp 25,6 \mathrm{pg} / \mathrm{ml})$. La concentration de $1,25-(\mathrm{OH})_{2} \mathrm{D}_{3}$ artérielle plasmatique chez les fotus de truies homozygotes est seulement de $46 \%$ de celle des fœtus de truies normocalcémiques, ce qui témoigne du transfert du calcitriol de la mère au fotus.

On conclut de ces études que chez le cochon, la produc- 
tion rénale et les concentrations physiologiques de 1,25$(\mathrm{OH})_{2} \mathrm{D}_{3}$ chez la mère et chez le fœtus ne sont pas essentielles pour la maintenance de l'homéostasie du ca et du P dans le système fœtomaternel.

Mots-clés: Calcium, 1,25-(OH) $)_{2} \mathrm{D}_{3}$, phosphore, rachitismes par carence en pseudovitamine $\mathrm{D}$, type I, transport placentaire, vitamine D.

\section{References}

[1] BAWDEN JW, AS Jones, CE Flowers: Maternal, fetal blood calcium relationship in sheep. Obstet Gynecol 25 (1965) 548

[2] Brommage R, HF Deluca: Placental transport of calcium and phosphorus is not regulated by vitamin D. Am J Physiol 246 (1984) F526

[3] BRUnS MEH, A FAusto, LV Avioli: Placental calcium binding protein in rats. J Biol Chem 253 (1978) 3186

[4] BRuns MEH, DE BRuns: Vitamin D-metabolism and function during pregnancy and neonatal period. Ann Clin Lab Sci 13 (1983) 521

[5] Care AD: Calcium homeostasis in the fetus. J Dev Physiol 2 (1980) 85

[6] Care AD, R Ross, DW Pickard, AD Weatherby, JM Garel, RM Manning, J Algrove, S PapaPOULOS, R O'RHIORDAN: Calcium homeostasis in the fetal pig. J Dev Physiol 4 (1982) 85

[7] Fenton E, HG BRITTON: 25-hydroxycholecalciferol-1 $\alpha$-hydroxylase activity in the kidney of the fetal neonatal and adult guinea pig. Biol Neonate 37 (1980) 254

[8] Gray TK, GE LESTER, RS LORENC: Evidence for extrarenal $1 \alpha$-hydroxylation of 25 -hydroxyvitamin $\mathrm{D}_{3}$ in pregnancy. Science 204 (1979) 1311

[9] Halloran BP, H Deluca: Effect of vitamin D on skeletal development during early growth in the rat. Arch Biochem Biophys 209 (1981) 7

[10] Harmeyer J, C v Grabe, I Winkler: Pseudovitamin $\mathrm{D}$ deficiency rickets in pigs. An animal model for study of familial vitamin D dependency rickets. Exp Biol Med 7 (1982) 115

[11] KaUne R, J HaRmeYer: Die quantitative Bestimmung von Vitamin $\mathrm{D}$ und seiner Metaboliten im Plasma. Biol Chem Hoppe Seyler 367 (1986) 1135

[12] Kaune R, B Schröder, J HaRmeyer: Measurements of the intestinal $1,25-(\mathrm{OH})_{2} \mathrm{D}_{3}$ receptor and calcium transport in the piglets with pseudovitamin D deficiency rickets, type I. Pflugers Arch, Supplement to volume 406 (1986) R52

[13] KAUNE R, J HARMEYER: Eine erbliche Störung des Vitamin D Stoffwechsel bei Schweinen. Die Pseudovitamin D Mangelrachitis, Typ I. Berl Münch Tierärztl Wschr 100 (1987) 006

[14] LACHENMAIER-CURRLE U, J HARMEYER: Intestinal absorption of calcium in newborn piglets, the role of Vitamin D. Biology of the Neonate 53 (1987) 327
[15] Lambert PW, PB Deoreo, BW Hollis, JY Fu, DJ GINSBERG, BA Ross: Concurrent measurement of plasma levels of vitamin $D_{3}$ and five of its metabolites in normal humans, chronic renal failure patients, and anephric subjects. J Lab Clin Med 98 (1981) 536

[16] Marche P, A Delorme, C Cuisinier-Gleizes: Intestinal and placental calcium-binding protein in vitamin D-deprived or supplemented rats. Life Sci 23 (1978) 2555

[17] Moore FS, CBL Langman, MJ Favus, M Ocampo, M LOGHMAN-ADHAM, FL COE: Role of fetal kidneys in calcium homeostasis in utero. In: Norman $A W$, $U$ Schaefer, D v Herrath, HG Grigoleit: Vitamin D, Chemical, Biochemical and Clinical Endocrinology of Calcium Metabolism, de Gruyter, New York 1982

[18] Pike JW, LL Grooze, MR Haussler: Biochemical evidence for $1,25-(\mathrm{OH})_{2} \mathrm{D}_{3}$ receptor macromolecules in parathyroid, pancreatic pituitary and placental tissues. Life Sci 26 (1980) 407

[19] Plonait H: Erbliche Rachitis der Saugferkel. Pathogenese and Therapie. Zbl Vet Med A 16 (1969) 271

[20] Prader A, R Illig, E Heierli: Eine besondere Form der primären Vitamin $D$ resistenten Rachitis mit Hypocalcämie und autosomaldominantem Erbgang, die hereditäre Pseudo-Mangelrachitis. Helv paediatr acta 16 (1961) 452

[21] Richterich R: Klinische Chemie Theorie und Praxis. Adadem Verl Ges, Frankfurt a. M. 1965

[22] Ross R, AD Care, JS Robinson, DW Pickard, AJ WeAtherby: Perinatal $1,25-(\mathrm{OH})_{2} \mathrm{D}_{3}$ in the sheep; involvement of fetal maintainance of the transplacental calcium gradient. In: COHEN DV, RV TALMAGE, JL MATTHEWS: Hormonal control of calcium metabolism. Proc. $7^{\text {th }}$ Int Conf calcium regulating hormones. $7^{\text {th }}$ Parathyroid Conf Colorado, USA, Excerpta Medica, Amsterdam 1981

[23] Ross R: Vitamin D metabolism in the pregnant large animal. In: HoLICK MF, CS ANAST, TK GRAY: Perinatal calcium and phosphorus metabolism, Elsevier, Amsterdam, New York, Oxford 1983

[24] Tanaka Y, B Halloran, HK Schnoes, HF DeLUCA: In vitro produciton of 1,25-dihydroxyvitamin $\mathrm{D}_{3}$ by rat placental tissue. Proc Natl Acad Sci USA 76 (1979) 5033 
[25] Twardock AR, MK Austin: Calcium transfer in the persfused guinea pig palcenta. Am J Physiol 219 (1970) 540

[26] Weiman Y, A Vargas, G Duckett, E Reiter, AW RooT: Synthesis of 1,25-dihydroxyvitamin $D$ in the nephrectomized pregnant rat. Endocrinology 103 (1978) 1992

[27] Weisman Y, A Harell, S Edelstein, M David, Z SPIRER, A ColandER: $1 \alpha-25$-dihydroxyvitamin $D_{3}$ and 24,25-dihydroxyvitamin $D_{3}$ in vitro synthesis by human decedua and placenta. Nature 281 (1979) 317
[28] WiNKLER I, F SCHREINER, J HARMEYER: Absence of renal 25-hydroxycholecalciferol-1-hydroxylase activity in a pig strain with vitamin D-dependent rickets. Calcif Tissue Int 38 (1986) 87

Received August 17, 1987. Revised December 12, 1988. Accepted January 16, 1989.

Dr. Johein Harmeyer Physiologisches Institut Tierärztliche Hochschule Bischofsholer Damm 15 D-3000 Hannover 1 West Germany 